\title{
Experimental Set-up for Corrosion Study of Nitriding Surface Heat Treatment on MgAZ91D Magnesium Alloy
}

\author{
M. Faizairi M. Nor*1, Suhaimi Hassan2, M. Azman Zakariya3, Faizal A. Fadzil4, M. A. Aiman Azmi3 M.
} Zulkifli Mohd Rosli2, Jariah Mohammad Juoi3

1, 2 Department of Mechanical Engineering, 3 Department of Electrical Engineering, 4 Department of Information Technology , Universiti Teknologi Petronas

2,3 Faculty of Manufacturing, Universiti Teknologi Melaka, Air Keroh Melaka

Address For Correspondence:

M Faizairi M Nor, Department of Mechanical Engineering, Universiti Teknologi Petronas, Seri Iskandar 32610, Perak, Malaysia, Tel:603-3687009, E-mail: mfaizairi mnor@utp.edu.my

Copyright: (C) 2019 M. Faizairi M. Nor et al., This is an open-access article distributed under the terms of the Creative Commons Attribution License, which permits unrestricted use, distribution, and reproduction in any medium, provided the original author and source are credited.

\begin{abstract}
A B S T R A C T
MgAZ91D is an alloy which has high general strength, low density and high formability. Therefore, magnesium alloy, MgAZ91D is widely being used mainly in the aerospace, automotive and telecommunication industries. The main disadvantage of MgAZ91D is its low resistance towards corrosion attack. Therefore, this research objective is on improving the corrosion-resistant of magnesium alloy, MgAZ91D. Nitriding process surface heat treatment on the MgAZ91D substrate by subjecting the metal alloy with $95 \%$ nitrogen and $5 \%$ hydrogen gas environment in a heating chamber. The variables are time of exposure and temperature of the surface heat treatments. The nitrided samples will undergo immersion corrosion test to analyse the corrosion-resistant of the specimens. Further analysis on the microstructure formation, case depth and corrosion resistance correlation based on the test matrix. The experimentalsetup will determine the correct procedure and conclude the impact of surface heat treatment towards the corrosionresistant of MgAZ91D and improvement of the alloy.
\end{abstract}

Keywords: Magnesium Alloy; Nitriding; Case Depth; Corrosion

\section{INTRODUCTION}

With the enormous growth in technology that is present today, it has made almost everything possible. In engineering material, the advancement of technology has made it possible to explore different property of a material based on a different configuration of said material let it be its atomic composition, microstructure and others. Over the past several decades, corrosion study on alloy has been made by researches to improve corrosion property of an alloy. Generally, the alloy is a combination of one primary metal, (called the solvent) to other minor metal, (called the solute) or one metal to another element. The earth's crust consists of $2.7 \%$ of magnesium and it is recyclable material with low density and good machinability (Liu, et al., 2017). This study specifically concentrates on Magnesium alloy, MgAZ91D. The composition of MgAZ91D is 90\% of magnesium, $9 \%$ of aluminium and $1 \%$ of Zinc. The composition of the magnesium alloy has made itself to have excellent properties for instance low density, high specific strength and high recyclability (Shafiz, Mohd Rosli, Yusuf, \& Mohamad Juoi, 2016). In addition, Magnesium alloy MgAZ91D is also known by the ease of fabrication process in which made the production cost to be economically beneficial. These great properties were the reason in which MgAZ91D to be widely known in the telecommunication and automotive industries (Wan Zulkifli, Mohd Rosli, \& Mohamad Juoi, 2017).

As for every design and property of a system, product or in this case, a material composition which it also has its own flaws. MgAZ91D has the low surface hardness and low resistant towards corrosion. It has been 
generally known that heat treatment can improve corrosion rate of certain metal alloy. Corrosion studies on magnesium alloys are still not completely consistent (Ballerini, Bardi, Bignucolo, \& Ceraolo, 2005) Therefore, the experiment conducted applies surface heat treatment towards MgAZ91D specifically on Nitriding treatment, with variables in temperature and time to see the effects of corrosion-resistant. There are several techniques in achieving such surface heat treatment for instance through diffusion, plasma-assist physical vapour decomposition (PA-PVD) and duplex (a combination of diffusion and PA-PVD). However, this study will only focus on diffusion method. The objectives this research were to (i) study the mechanical properties effects of nitriding towards the corrosion-resistant of Magnesium alloy,(ii) to investigate the impact of surface heat treatment towards the corrosion-resistant of Magnesium alloy,(iii)to correlate nitriding case depth, temperature and time on the corrosion-resistant of Magnesium alloy.

\section{Materials and Methods}

The study will mainly focus on the effects of Nitriding surface treatments on Magnesium alloy, MgAZ91D. Understanding the correlation and effect of microstructure of the said alloy and its corrosion resistance is the main focus in this work. The study will consist of 5 stages, which is the preparation, the microstructure study, the surface treatment, the case-depth and the testing phase.

In the preparation stage, the specimen of MgAZ91D is acquired and the specimens will be cut into several pieces with certain dimensions for the purpose of the study. Secondly, in the second phase, several of the prepared specimens will undergo mechanical properties testing such as tensile test, scratch test, tensile testing, Brinell and Vickers hardness. Thirdly, the specimens will be treated with nitriding surface treatment with variance in temperature and time. Fourthly, a second study on the microstructure of the specimens after the heat treatment. Finally, the specimens will undergo corrosion testing to determine the corrosion resistance of the specimens before and after being treated.

\subsection{Magnesium alloy, MgAZ91D}

Magnesium alloys have a very important role in the applications in the automobile, aerospace and electronics for having to be a lightweight metal with unique combinations of properties (Mordike \& Elbert, 2001). The use of magnesium alloys has become significant due to a one-third lower density of magnesium compared with aluminium, improved damping ability, higher resistance to corrosion and better mechanical properties. The main alloying element in magnesium alloy is aluminium which is the main reason for being lightweight, low price, and relatively having higher corrosion and strength properties (Smola, Stuli'kova', Von Buch, \& Mordike, 2002).

"The AZ91 alloy (contains about 9 wt. \% Al and 1 wt. \% Zn, with addition of about 0.4 wt. \% Mn) is the most widely used magnesium alloy exhibiting a good combination of high strength at room temperature, good castability and excellent corrosion resistance" (Czerwinski, 2011). Based on the figure below, the microstructure of $\mathrm{Mg}-\mathrm{Al}$ alloys is essentially based on the solid solution of aluminium in magnesium, the $\alpha$ phase and the $\gamma$-phase.

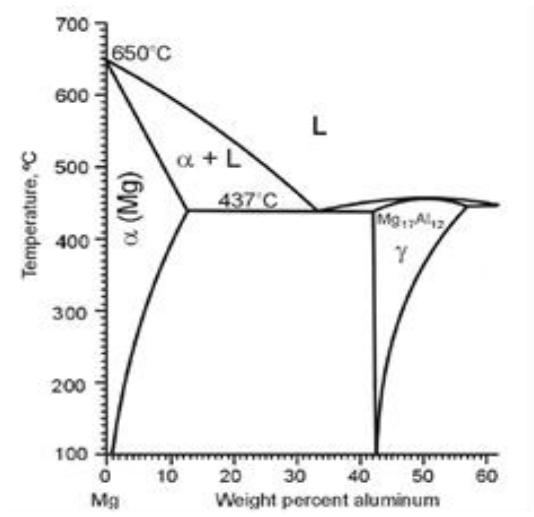

Figure 1: Fragment of Mg-Al phase diagram (adopted from Magnesium alloy - Design, processing and properties)

The table 1 shown below is the list of the composition of commonly used magnesium alloy. As per shown, MgAZ91D consist of $90 \%$ of Magnesium, $9 \%$ of Aluminum (the main alloying element), $0.005 \%$ max of Iron, $0.33 \%$ of Manganese, $0.002 \%$ max of Nickle and $0.7 \%$ of Zinc.

Table 1: List of commonly used magnesium alloys 
3 M. Faizairi M. Nor et al, 2019/Research Journal of Social Sciences 12(1), January-April, Page(1-7)

\begin{tabular}{|c|c|c|c|c|c|c|c|}
\hline Designation & $\mathrm{Al}$ & $\mathrm{Fe}(\max )$. & Mn & $\mathrm{Ni}(\max )$. & RE & $\mathrm{Si}$ & $\mathrm{Zn}$ \\
\hline AJ52A & 5 & 一 & 0.38 & - & 2.0 (Strontium) & - & 0.2 \\
\hline AJ62A & 6 & - & 0.38 & - & 2.5 (Strontium) & - & 0.2 \\
\hline AM50A & 4.9 & 0.004 & 0.32 & 0.002 & - & - & 0.22 \\
\hline AM60B & 6.0 & 0.005 & 0.42 & 0.002 & - & - & 0.22 (max.) \\
\hline AS41B & 4.2 & 0.0035 & 0.52 & 0.002 & - & 1.0 & 0.12 \\
\hline AZ31B & 3 & 0.005 & 0.6 & 0.005 & - & - & 1.0 \\
\hline AZ61A & 6.5 & 0.005 & 0.33 & 0.005 & - & - & 0.9 \\
\hline AZ80A & 8.5 & 0.005 & 0.31 & 0.005 & - & - & 0.5 \\
\hline AZ81A & 7.6 & - & 0.24 & - & - & - & 0.7 \\
\hline AZ91D & 9 & 0.005 & 0.33 & 0.002 & - & - & 0.7 \\
\hline AZ91E & 9 & 0.005 & 0.26 & 0.001 & - & - & 0.7 \\
\hline \multicolumn{8}{|c|}{ (b) Other Elements as Main Alloying Element } \\
\hline Designation & $\mathrm{Ag}$ & $\mathrm{Fe}(\max )$. & Mn & Ni (max.) & RE & $\mathrm{Zn}$ & $\mathrm{Zr}$ \\
\hline EZ33A & - & - & - & - & 3.2 & 2.5 & 0.7 \\
\hline $\mathrm{K} 1 \mathrm{~A}$ & - & - & - & - & - & - & 0.7 \\
\hline M1A & - & - & 1.6 & - & - & - & - \\
\hline QE22A & 2.5 & - & - & - & 2.2 & - & 0.7 \\
\hline WE43A & - & 0.01 & 0.15 & 0.005 & 4 (Yttrium) & 0.2 & 0.7 \\
\hline WE54A & - & - & 0.15 & 0.005 & 5.1 (Yttrium) & - & 0.7 \\
\hline ZE41A & - & - & 1.5 & - & 1.2 & 4.2 & 0.7 \\
\hline ZE63A & - & - & - & - & 2.6 & 5.8 & 0.7 \\
\hline ZK40A & - & - & - & - & - & 4.0 & 0.7 \\
\hline ZK60A & - & - & - & - & - & 5.5 & 0.7 \\
\hline
\end{tabular}

Magnesium, magnesium alloy, magnesium composites)

\subsection{Surface treatment}

\subsubsection{Diffusion}

Diffusion is a process in which material is being transported by the motion and movement of atoms (Calister $\&$ Rethwisch, 2009). The mechanism of diffusion is through the movement of atoms from one lattice position to another lattice position. The requirement in which this process required for such movement can be achieved is by two conditions. First, there must be an empty adjacent site and energy is enough for the migrating atom to break its bond with the current neighbouring atom (Callister, 2007).

Two types of motion in which atoms migrate through diffusion which is vacancy diffusion and interstitial diffusion. Vacancy diffusion includes migration of atoms from a normal lattice position to another normal lattice position while interstitial diffusion includes atoms that migrates from an interstitial position to another interstitial position.

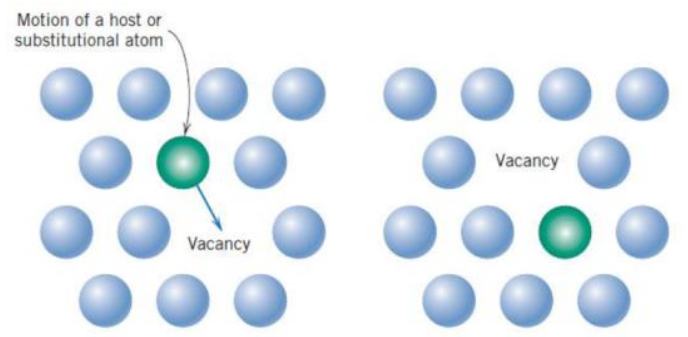

Figure 2. Movement of atom through substitutional diffusion. 


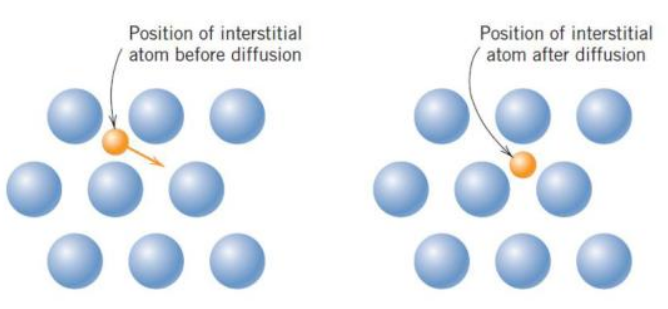

Figure 3: Movement of atom through interstitial diffusion

\subsubsection{Gas Nitriding \& Gas Oxidizing}

In general, Gas Nitriding is a surface treatment process in which an alloy is being exposed to a Nitrogen-rich environment. By diffusion mechanism in which has been discussed previously, the gas atoms will diffuse into the said alloy to create a layer at the surface of the alloy. Traditionally, the methods in which has been used to implement nitriding are through salt bath nitriding, ion nitriding and plasma or gas nitriding (Weymer, 2009)). In Nitriding process, Nitrogen atom can be formed on a metal piece through the decomposition of ammonia (NH3), (Weymer, 2009). Following chemical equation represents the decomposition of ammonia:

$$
\mathrm{NH}_{3} \rightarrow[\mathrm{N}]+3 / 2 \mathrm{H}_{2}----------------(1)
$$

In Oxidizing, oxygen can diffuse into magnesium surface to form oxidation (Shafiz, Mohd Rosli, Yusuf, \& Mihamad Juoi, 2016). The following chemical equation shows the decomposition of oxygen gas to form oxides layer on magnesium.

$$
2 \mathrm{Mg}+\mathrm{O}_{2} \rightarrow 2 \mathrm{MgO}
$$

The rate of diffusion of both Nitriding and Oxidizing are affected by three factors, the temperature of the process, the content of the alloy and the concentration of gas in the gas rich environment (Weymer, 2009).

\subsection{Corrosion of Magnesium.}

Corrosion can be defined as an unintentional or intentional attack of a metal electrochemically and ordinarily begin at the surface of the before mentioned metal (Calister \& Rethwisch, 2009). The characterization of a metal that give away electron to form a metal ion is called as oxidation. The electrochemical equation in which can illustrate the corrosion of metal $\mathrm{M}$ can be described as below:

$$
M \rightarrow M^{n^{+}}+n e^{-1}--------------------(3)
$$

In case of corrosion for magnesium, the low corrosion resistance is mainly due to two key factors. The high electronegative potential of $\mathrm{Mg}$ which enable corrosion even without the presence of oxygen and the poorly properties of any surface film that can be produced by $\mathrm{Mg}$ which implies that any hydroxides or oxides that form on $\mathrm{Mg}$ are soluble when exposed to humidity (Esmaily, et al., 2017). Below are the electrochemical equations of $\mathrm{Mg}$ corrosion process through the surface with the presence of oxygen and water.

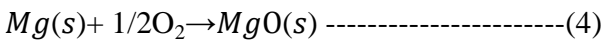

$$
\begin{aligned}
& \mathrm{MgO}(\mathrm{s})+\mathrm{H}_{2} \mathrm{O} \rightarrow \mathrm{Mg}(\mathrm{OH}) 2(\mathrm{~s}) \text {---------------(5) } \\
& \mathrm{Mg}(\mathrm{OH})_{2} \rightleftharpoons \mathrm{Mg}^{2+}(a q)+2(\mathrm{OH})^{-}(a q) \text {----------(6) }
\end{aligned}
$$

As per illustrated, with the presence of both water and oxygen, magnesium has transformed from magnesium atom, $\mathrm{Mg}$ to magnesium ion, $\mathrm{Mg}^{2+}$ through oxidation of increasing in oxidation number from 0 to $2+$.

\subsection{Microstructure analysis equipment.}

\subsubsection{X-ray Diffraction (XRD)}

The main purposes of XRD are to firstly identify the crystalline phases and orientation of the unit cell of the magnesium alloy, MgAZ91D. Secondly, the purpose is to measure the thickness of thin films or the case-depth produce after nitriding. In general, diffraction effects occur due to the constructive and destructive interference that is being diffracted by the crystalline and molecular structure of the material, (Birkholz, 2006) 


\subsubsection{Scanning Electron Microscope (SEM)}

Essentially, through SEM, electron beam scan throughout the surface of the specimen, which results in the transfer of energy to the surface area. The electrons that are being bombarded to the surface called primary electrons will dislodge electrons from the specimen. The dislodged electrons are called secondary electrons, will be detected and translated into signals. Each element has specific characteristic signal (Zhou, Apkarian, Wng, \& Joy, NA). Therefore, through this method the surface topology of the magnesium alloy, MgAZ91D can be determined.

\subsubsection{Energy Dispersive X-ray Spectroscopy (EDX)}

The purpose of EDX is to obtain the elemental composition of a specimen. Generally, the X-ray spectrum is emitted by a solid specimen which is bombarded with a focused beam of electrons which results in obtaining the localized composition of the specimen. The process is much like SEM however in EDX, it will produce an elemental distribution of the specimens (Hafner, NA). Therefore, through EDX the author can determine the elemental distribution on the surface of magnesium alloy, MgAZ91D.

\subsection{Corrosion test: Mass Loss Laboratory Immersion Corrosion Test}

In this part of the literature review, the means of determination of the corrosion rate of treated MgAZ91D will be discussed based on ASTM standards G1 Standard Practice for preparing, cleaning and evaluating test specimens and ASTM G31 Standard Practice for Laboratory Immersion Corrosion Testing of Metals. The procedure of the corrosion test is divided into a few steps. Firstly, the specimens are to be cleaned and weigh to evaluate the initial weight.

The standard suggests a weighing scale minimum of 3 decimal places. Secondly, the specimen is then to be immersed in a corrosive media. Brine Solution is used as corrosive media. The immersion time is 24 hours, (ASTM Standard G1, 1999). After the immersion test completed, the specimens are clean by scrubbing using metallic bristle brush. However, due to mechanical cleaning, mass loss of the base metal usually occur. This will cause error in the calculation to evaluate the corrosion rate of the specimen in the next stage.

Therefore, a control specimen that has not undergo the surface treatment will undergo the same process of scrubbing and the mass loss of the control specimen will be taken into consideration. The weighted mass loss of the control specimen is use to fix the value of the treated specimen to reduce error (ASTM Standards G31, 2004). The corrosion rate will be calculated based on the equation below:

$$
\text { Corrosion Rate }=K \times\left(m_{\text {final }}-m_{\text {initial }}\right) / \rho \times A s \times t-------(7)
$$

$\mathrm{K}$ - Constant to convert the corrosion rate to $\mathrm{mm} / \mathrm{year} 8.76 \times 10^{4}$

$\mathrm{m}$ - Mass of the specimen, $\mathrm{g}$

$\rho$ - Density of magnesium alloy, $1.74 \mathrm{~g} / \mathrm{cm}^{2}$,

As - Surface area, $\mathrm{cm}^{2}$

$\mathrm{t}$ - Immersion time, hours

\subsection{Methodology/ Project Work}

\subsection{Project details}

As per stated previously, in total there are 4 stages in this project. The first step is to prepare the samples of magnesium alloy. The samples are prepared by cutting the sample into smaller pieces with $10 \mathrm{~mm} \times 10 \mathrm{~mm} \times 10 \mathrm{~mm}$ for corrosion testing and $20 \times 20 \times 20$ for microstructure testing. The means in which the specimens are cut using an abrasive cutter with a cooling system to protect the specimen microstructure of any additional heat.

Secondly, after the preparation of the samples has been completed, microstructural, property and morphological study will be done before any heat treatment has been applied to the specimen to act as a control and comparison to the results later on. Below is the test equipment that will be used and the parameters or property to be measured from the specimen.

Table 4: Summary of equipment for microstructure analysis and the property to be analysed.

\begin{tabular}{|l|l|}
\hline Equipment & Property \\
\hline $\begin{array}{l}\text { Scanning } \text { Electron } \\
\text { Microscope (SEM) }\end{array}$ & $\begin{array}{l}\text { Surface topology of the Magnesium } \\
\text { alloy, MgAZ91D. } \\
\text { \& microstructure }\end{array}$ \\
\hline $\begin{array}{l}\text { Field Emission Scanning } \\
\text { (FE-SEM) }\end{array}$ & $\begin{array}{l}\text { Determine the cell size and pore size of } \\
\text { the specimens, MgAZ91D. }\end{array}$ \\
\hline $\begin{array}{l}\text { X-ray Diffraction } \\
\text { XRD) }\end{array}$ & $\begin{array}{l}\text { Determine the unit cell dimensions for } \\
\text { the magnesium alloy, MgAZ91D. }\end{array}$ \\
\hline $\begin{array}{l}\text { X-ray Fluorescence } \\
\text { XRF) }\end{array}$ & $\begin{array}{l}\text { Determine the elemental composition of } \\
\text { the magnesium alloy, MgAZ91D. }\end{array}$ \\
\hline
\end{tabular}

\subsection{Design of experiment}


Through this research, the parameters that are being manipulated are temperature and the time period in which the surface heat treatment is being conducted on MgAZ91D specimens. Through lab immersion corrosion test, the author will then know the output of the combination from each experiment. In order to determine the weight factor in which the parameters have towards the outcome of the investigation, the corrosion rate of treated MgAZ91D specimens, the author has adopted the "Taguchi method". Through this method, Taguchi uses a unique design of orthogonal arrays that allows studying the whole parameter space with the limited number of experiments (Rosa, Robin, Silva, Baldan, \& Peres, 2009).

The values of each parameter are as below:

a) Surface heat treatment-Nitriding

b) Time period of heat treatment: 1 hour \& 2 hours

c) Temperature of surface heat treatment: $300,400 \& 500{ }^{\circ} \mathrm{C}$

\subsection{Project flow chart}

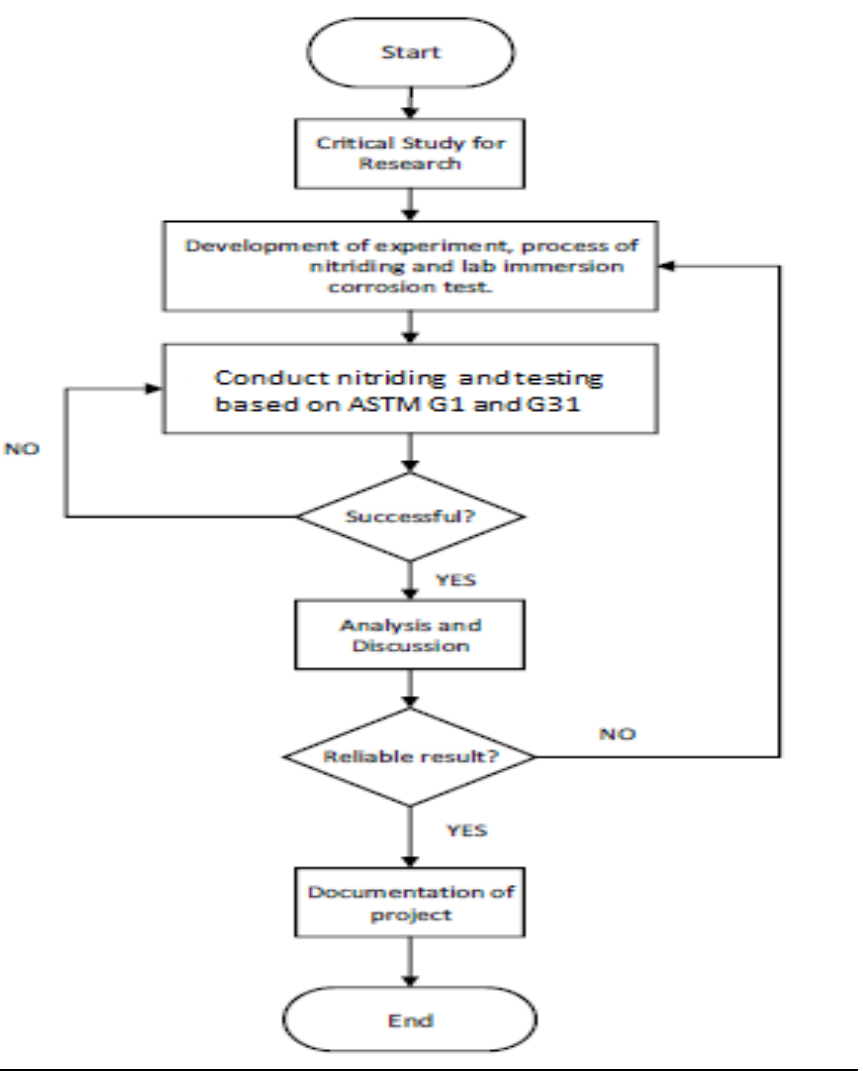

Figure 4: Research flowchart

\section{Conclusion}

The intention of the experiment is to understand the behavior and performance of Magnesium Alloy, Mg AZ91D with Nitrogen coating. The hypothesis for corrosion is a reduction and improvement to the substrate from material degradation. Mechanical properties improve by increasing the case depth to the substrate. The corrosion protection depends on the layer of nitride coating and the case depth of layer formation.

\section{Authors' Contribution}

Dr Suhaimi Hassan, Mr Faizal A. Fadzil and Mr M.A Aiman Azmi developed the idea and had an essential role in the result and material section. Dr Azman Zakariya, Dr Zulkifli Mohd Rosli and Dr Jariah Juoi performed the statistical analysis, the discussion and the abstract submission.

\section{References}

1. A.D., F., I.L., L., \& S.B., S. (2017). Anodisation of AZ91D magnesium alloy in molybdate solution for corrosion protection. Journal of Alloys and Compounds, 338-345.

2. ASTM Standard G1. (1999). 
3. ASTM Standards G31 . (2004).

4. Ballerini, G., Bardi, U., Bignucolo, R., \& Ceraolo, G. (2005). About some corrosion mechanism of AZ91D magnesium alloy. Corrosion science, 2173-2184.

5. Birkholz, M. (2006). Principles of X-ray Diffraction. In M. Birkholz, Thin FIlm Analysis by X-Ray Scattering.

6. Calister, W. D., \& Rethwisch, D. G. (2009). Materials Science and Engineering: An Introduction. United States of America: ISBN.

7. Callister, W. D. (2007). Materials Science and Engineering: an Introduction. United States of Americe: ISBN.

8. Czerwinski, F. (2011). Magnesium Alloys - Design, Processing and Properties. Rijeka, Croatia: Intech.

9. Esmaily, E., Svensson, J., Fajardo, S., Birbilis, S., Frankel, G., Virtanen, S., . . . Johansson, L. (2017). Fundamentals and advances in Magnesium alloy corrosion. Progress in Materials Science, 92-193.

10. Hafner, B. (NA). Energy Dispersive Spectroscopy on SEM: A Prmer. Hongxia, W., Bin, Y., Weiwei, W., Guangxiao, R., Wei, L., \& Jinshan, Z. (2014). Improved corrosion resistance of AZ91D magnesium alloy by a zinc-yttrium coating. Journal of Alloys and Compounds, 457-460.

11. Jianfang, L., Xiaojing, H., Ruiqiang, H., Xiaobo, H., Xiangyu, Z., \& Bin, T. (2017). Fabrication and corrosion behavior of $\mathrm{TiO} 2$ nanotubes on AZ91D magnesium alloy. Ceramics International, 13683-13688. 31

12. Liu, C., Li, Z., Pei, X., Yang, L., Zhang, Y., \& Wei, S. (2017). Microstructure and properties of AL-SI alloy cladding on AZ91D magnesium alloy by low heat input DC-PMIG welding. Surface and Coating Technology, 42-48.

13. Mordike, B., \& Elbert, T. (2001). Magnesium, Properties-applications-potential. MAterial Science and Engineering A302, 37-45.

14. Nan, S., Yanhua, L., Atsui, H., Mikito, U., \& Toshiaki, O. (2014). Improvement of polypyrrole films for corrosion protection of zinc-coated AZ91D alloy. Progress in Organic Coatings, 1724-1734.

15. Pye, D. (2003). An introduction to Nitriding. In D. Pye, Practical NItriding and Ferritic Nitrocarburizing (pp. 1-13). United States of America: ISBN.

16. Rosa, J., Robin, A., Silva, M., Baldan, C., \& Peres, M. (2009). Electrodeposition of copper on titanium wires: taguchi experimental design appraoch. Journal of Materials processing technology, 1181-1188.

17. Shackley, M. S. (2011). Chapter 2: an Introduction to X-Ray Fluorescence (XRF) Analysis in Archaelogy. In M. S. Shackley, X-Ray Fluorescence Spectography $(X R F)$ in GEoarchaeology (pp. 7-44).

18. Shafiz, W. A., Mohd Rosli, Z., Yusuf, Y., \& Mihamad Juoi, J. (2016). Enhancing Corrosion Performanceof AZ91D Surface via Diffusion, PA-PVD and Duplex Treatment: A comparison Study. Advanced Science Letters, $1-4$.

19. Smola, B., Stulı'kova', F., Von Buch, F., \& Mordike, B. (2002). Structural aspects of high performance Mg alloy design. Material Science and Engineering, 113-117.

20. Wan Zulkifli, W. A., Mohd Rosli, Z., \& Mohamad Juoi, J. (2017). Effect of Nitriding Temperature and NItriding TIme on MgAZ91D. Journal of Mechanical Engineering, 177-184.

21. Weymer, P. (2009). Principles of Gas Nitriding. Heat Treatment Progress, 12-13.

22. Ya-ru, Z., Shan, Z., Lin-lin, N., Jian-qing, Z., Fa-he, C., \& Jun-xi, Z. (2016). Electrodeposition and corrosion resistance of $\mathrm{Ni}-\mathrm{P}-\mathrm{TiN}$ composite coating on AZ91D magnesium alloy. Transactions of Nonferrous metals society of China, 2976-2987.

23. You, S., Huang, Y., Kainer, K. U., \& Hort, N. (2017). Recent research and developments on wrought magnesium alloys. Journal of Magnesium and Alloys, 1-15. 